Proc. Estonian Acad. Sci. Geol., 2003, 52, 4, 239-265

\title{
Sedimentation of the Himmiste-Kuigu fish bed (Ludlow of Estonia) and taphonomy of the Phlebolepis elegans Pander (Thelodonti) shoal
}

\author{
Tiiu Märss ${ }^{\mathrm{a}}$, Helle Perens ${ }^{\mathrm{b}}$, and Tiiu Klaos ${ }^{\mathrm{c}}$ \\ ${ }^{a}$ Institute of Geology at Tallinn Technical University, Estonia pst. 7, 10143 Tallinn, Estonia; \\ marss@gi.ee \\ b Geological Survey of Estonia, Kadaka tee 82, 12618 Tallinn, Estonia; h.perens@egk.ee \\ c Institute of Geology, University of Tartu, Vanemuise 46, 52014 Tartu, Estonia; tiiuk@ut.ee
}

Received 26 February 2003, in revised form 19 May 2003

\begin{abstract}
Sediments with the squamations of Phlebolepis elegans Pander at Himmiste-Kuigu were formed in a lagoon of the Palaeobaltic Sea, situated in the tropical realm during Himmiste time of the Paadla Age, Ludlow, late Silurian. From the micro- and macrolithological features of the rocks, and the distribution of facies during Himmiste time it is concluded that the thelodonts died in a shallow depression on the bottom of the lagoon behind the reef belt towards the land; the depression acted as a trap during low tide. Unfavourable conditions, primarily the lack of oxygen in warm and shallow water, caused the perishing of the Phlebolepis shoal. Very low wave activity prevented postmortem disintegration of the squamation and rapid conservation in mud saved the exoskeletons from scattering.
\end{abstract}

Key words: Thelodonti (Agnatha), taphonomy, Estonia, Ludlow, Silurian.

\section{INTRODUCTION}

Phlebolepis elegans was established nearly 150 years ago by C. H. Pander (1856) on the basis of scattered scales. Since that time it has been found widely on the East European Platform (Baltic, Poland, Timan-Pechora Region, the Central Urals), in southern Britain, and the Severnaya Zemlya Archipelago. A. Luha (Fig. 1) discovered articulated specimens of Phlebolepis elegans Pander in the Himmiste-Kuigu locality when studying the Silurian beds on Saaremaa Island in 1929. Following excavations in the quarry produced extremely well preserved numerous specimens of P. elegans and also some osteostracans. A. Luha sent about 70 specimens of P. elegans for the study to J. Kiaer in Oslo, while he himself published only a short popular-scientific paper on the osteostracans of Saaremaa (Luha 1940). After J. Kiaer's death in 1931, A. Heintz finished the 


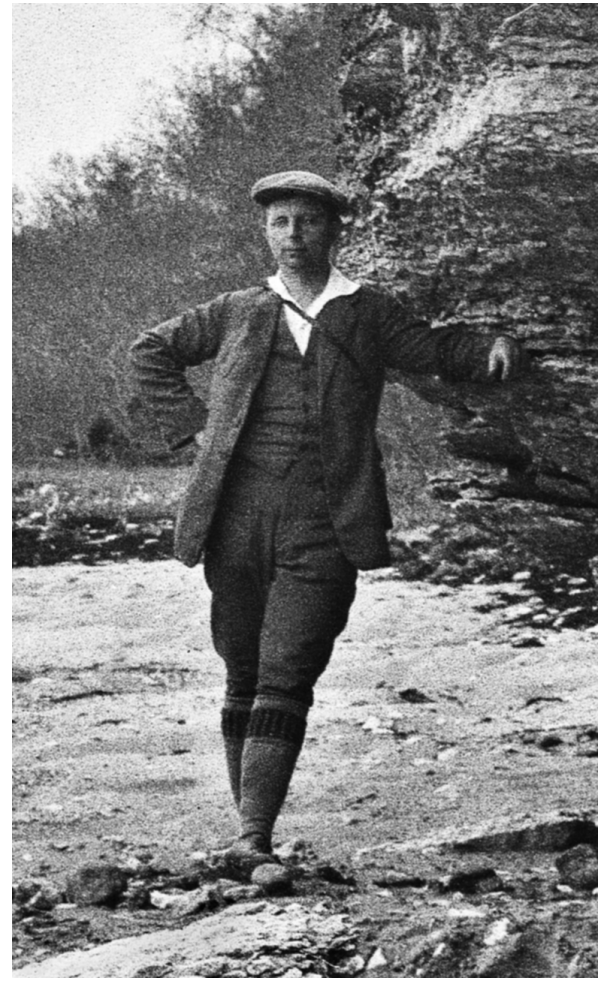

Fig. 1. Artur Luha (1892-1953) at field work in 1927. He discovered the bed rich in agnathan exoskeletons in the Himmiste-Kuigu quarry in 1929. paper. He named the taxon Coelolepis luhai Kiaer (Kiaer 1932), which Hoppe (1934) assigned to Phlebolepis elegans Pander 1856 (for a more detailed history of study see Märss 1986a).

In the literature the names Himmiste, Kuigu, and Himmiste-Kuigu have been equally used for the same quarry. An incorrect name for it is Atla (Patten 1931), since that locality is situated about $5 \mathrm{~km}$ to the northwest of Himmiste-Kuigu and has not yielded articulated agnathans or their shields and scales. The Himmiste-Kuigu quarry was opened sometime in the middle of the 19th century to supply the nearby farms with building stone. After the discovery of fish in 1929, the quarry was widened during several excavations. Specimens of P. elegans as well as osteostracans were exported to several museums in Europe and North America. One of the largest collections was extracted by local workers under the guidance of W. Patten (Dartmouth College) in 1930 and 1932. This collection, now housed at the American Museum of Natural History in New York (see Ritchie 1980), has not been studied by us. As a result of these diggings, the lens with $P$. elegans was exhausted and later no articulated agnathan specimens have been found apart from a few Tremataspis mammillata Patten and Dartmuthia gemmifera Patten shields. Today the Himmiste-Kuigu quarry is abandoned. Though, it is not excluded that another lens may occur somewhere nearby, i.e. in another depression that existed on the bottom of a shallow lagoon.

Originally A. Luha's collection of P. elegans belonged to the University of Tartu. In 1947 it was handed over to the Institute of Geology of the Academy of Sciences of Estonia and, together with the specimens returned from Oslo, it formed part of the Silurian vertebrate collection of the institute. Over 250 specimens were studied and numbered (Märss 1979, 1986a, 1986b). In 1995 it was decided to return the vertebrate collection to the university, which necessitated the revision of the articulated P. elegans material from the Himmiste-Kuigu quarry. During the revision several unstudied slabs with beautifully preserved specimens were discovered. 
The present study makes use of both the recently found and previously described material. It concentrates on the lithology and facies development of the Paadla Stage (by H. Perens), microlithology of the fish bed at Himmiste-Kuigu (T. Klaos), and burial of the thelodont shoal and its preservation conditions (T. Märss). Some new morphological features of P. elegans (e.g. of the caudal fin, pineal area, etc.) were discovered, which will be described in detail in a forthcoming paper.

\section{MATERIAL AND METHODS}

\section{Material}

The collection consists of 48 slabs of different size, each bearing more than one specimen (see Table 1); small pieces of rock with fragmentary specimens were not used in this study. Thirteen slabs have a maximum length of $50 \mathrm{~cm}$ or more (the largest measurements are $70 \times 45 \mathrm{~cm}$ ), 13 - between 30 and $50 \mathrm{~cm}$, and 22 - between 18 and $30 \mathrm{~cm}$. The maximum thickness of the fish bed is $14 \mathrm{~cm}$. The about $1.5 \mathrm{~cm}$ thick layer with $P$. elegans exoskeletons divides the fish bed into the lower and upper parts of variable thickness (Table 1).

The P. elegans specimens are very variably preserved. The colour of the scales changes from white and light beige to dark coffee-brown. The moulds left from the scales have usually perfectly preserved sharp edges but are weathered in some slabs. In the rocks where the fissures have been secondarily filled with transparent dolomite, the scale depressions have also been filled with this mineral during the postsedimentary processes.

\section{Methods}

First the rock pieces which fitted with each other were found and glued together. Then the squamations on all slabs were drawn from the stone directly to transparent plastic using a magnifier. At the same time the anterior and posterior ends of specimens were determined and it was found out whether the specimens were dorso-ventrally or laterally compressed. The surface of the rock was moistened with water for study and photographing in order to make thelodont squamations more contrast.

The sides of most of the slabs show arrows carved by the collector, pointing to the base of the bed. No marks or fieldnotes were left defining the quarters of excavated slabs. Therefore the positions of $P$. elegans bodies were studied with regard to each other and the directions of longer axes of specimens were measured on separate slabs to find out any regularity. If the specimen was twisted, then the anterior part of the body was used for that purpose. Based on the measurements, the rose diagrams showing orientation of specimens were drawn separately for each set of slabs which existed under the same collection number. 


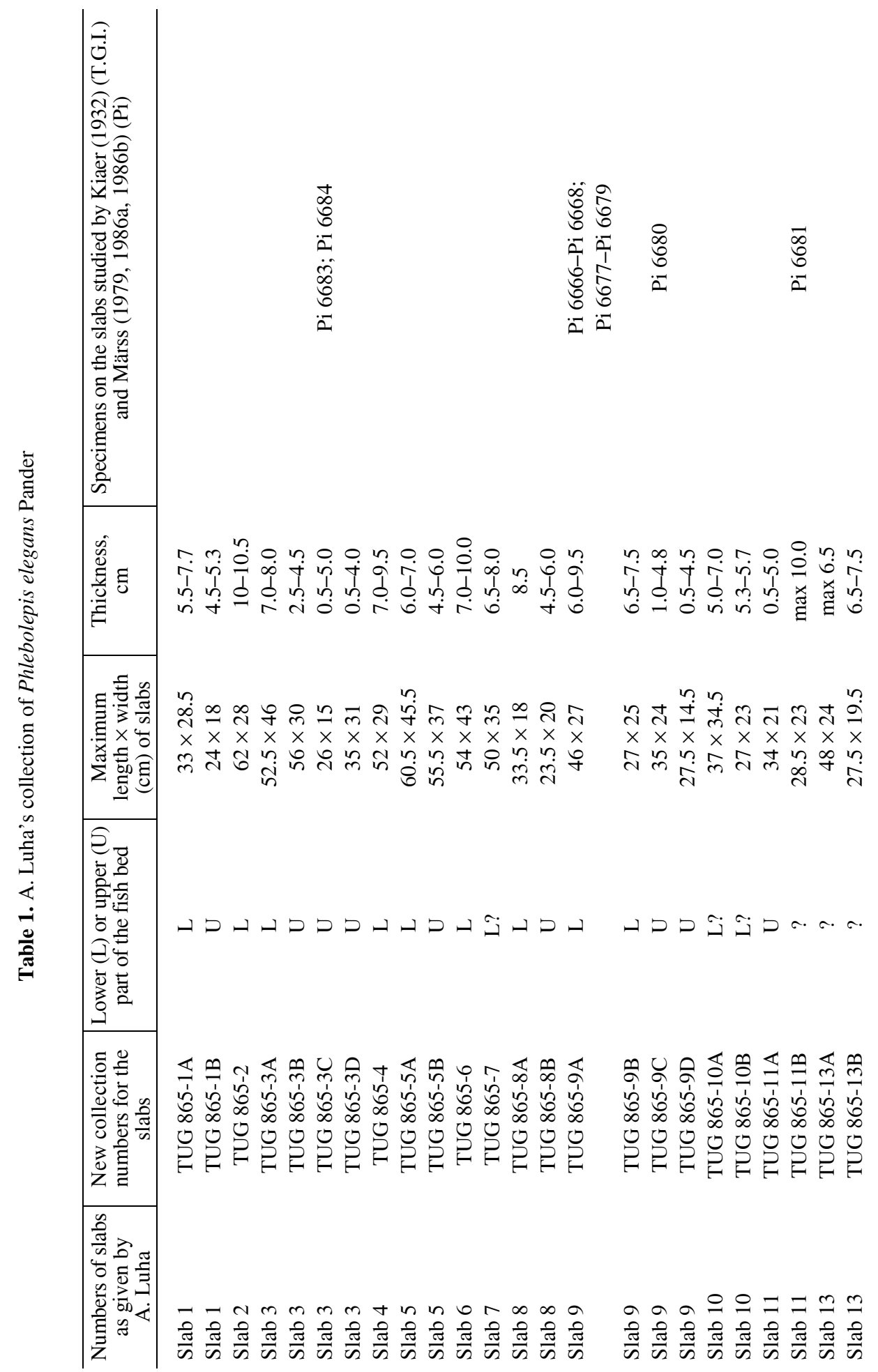




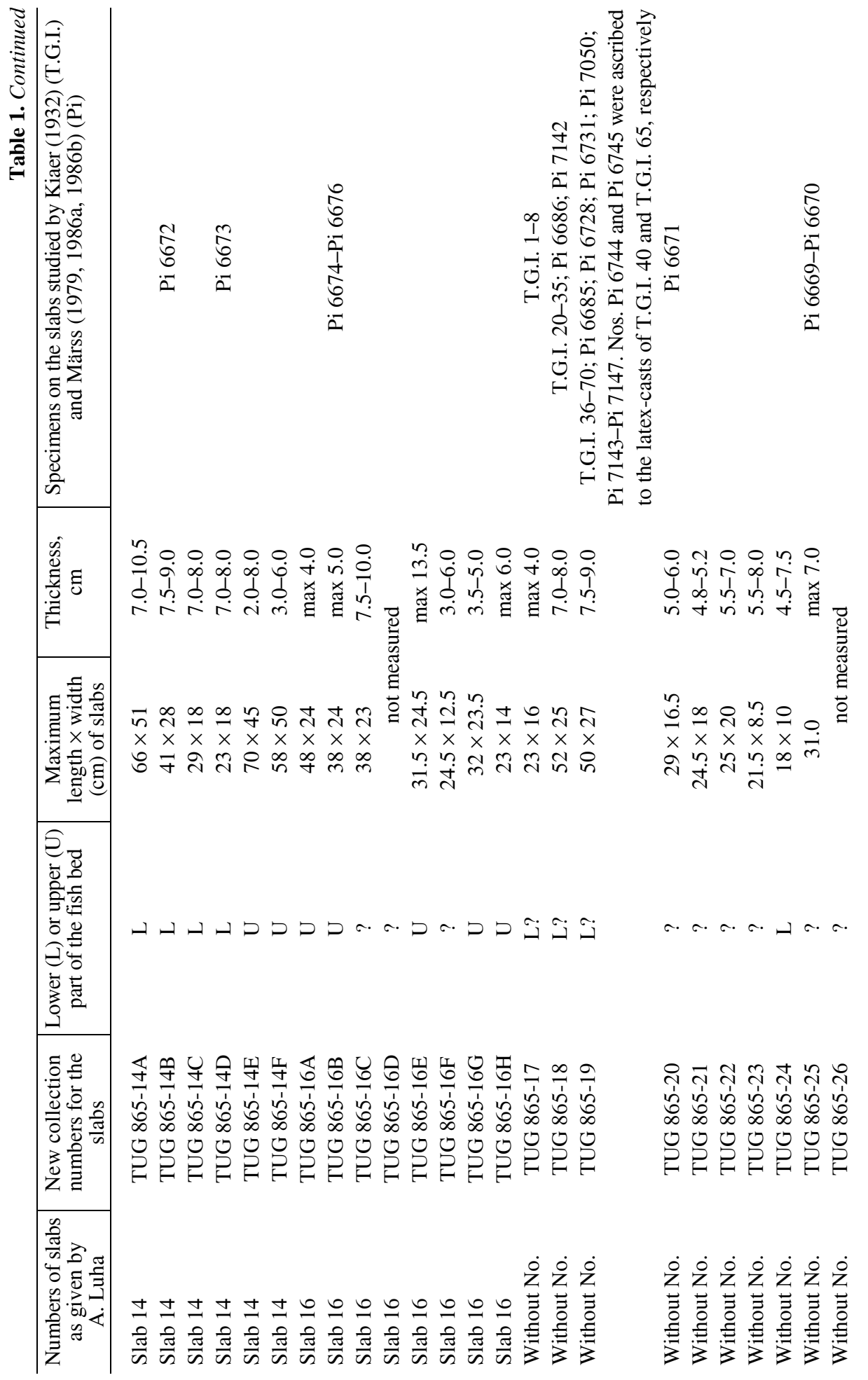


Facies development during the Paadla Age was studied on the basis of macrolithological features and chemical content of rock samples from 31 drill cores of Saaremaa. As the fish bed was complete in few slab corners, its microlithology was investigated in thin sections as well as on the polished vertical surface. The mineralogical composition of the fish bed was studied by the XRD method in four samples, three from below and one from above the fish layer.

\section{LITHOLOGY OF THE PAADLA STAGE}

In the outcrop area on Saaremaa Island, the rocks of the Paadla Stage stretch as a $7 \mathrm{~km}$ wide zone from the west to east coast, the extreme marginal points being Roopa and Hülge cliffs, respectively. In that area the Paadla Stage is represented by the Paadla Formation; southwards, on the Sorve Peninsula, by the Torgu Formation, and eastwards, on Kihnu Island and continental Estonia, by the Kihnu Formation (Aaloe et al. 1976). On the basis of the cyclic composition of the rocks, the Paadla Formation is divided into three units, the lowest being the Sauvere Beds which are overlain by the Himmiste and Uduvere beds (see Nestor 1997). The cyclicity is also evident in the gamma-log, showing two distinct curves for the Sauvere Beds and one for the Himmiste Beds (on the top left in Fig. 2). The beds are exposed in several outcrops and pierced in 31 cores, ten of which are shown in Fig. 2 (for location see Fig. 10).

The Sauvere Beds $\left(K_{2} S\right.$ in Fig. 2$)$ vary in thickness from 9 to $15 \mathrm{~m}$; their lower boundary is marked by strong, often multiple, pyritized discontinuity surfaces. In the section of the Kaarma quarry (thickness $3.8 \mathrm{~m}$ ) the beds are characterized by weakly argillaceous, porous, microlaminated, massive (up to $1 \mathrm{~m}$ thick layers) dolostones, so-called dolostones of Kaarma type (see also Einasto 1990), which in the eastern sections alternate with kerogenous and vuggy dolostones (Vätta-817 core, depth 54.0-56.0 m; Nässumaa-825 core, depth 55.2$57.0 \mathrm{~m}$ ). The maximum thickness of this type of beds in the Tahula-709 core is $6.5 \mathrm{~m}$ (depth 24.0-30.5 m). In Kaarma-type dolostones the content of $\mathrm{CaO}$ is 28.6-30.65\%, $\mathrm{MgO}-18.49-18.8 \%$, insoluble residue (i.r.) - 4.23-7.48\%.

The Sauvere Beds to the east of Kuressaare (Vätta-817 core, depth 54.0-65.5 m; Nässumaa- 825 core, depth $55.2-65.5 \mathrm{~m}$ ) are represented by typical brownish-grey or greenish-grey, wavy-bedded, argillaceous, kerogenous, bioturbated dolostone. The rocks are porous to vuggy. Upwards in the sections, in about the middle of the beds in the Vätta-817 core (depth 57.0-59.6 m), tabulate corals and stromatoporoids are present. In the Vätta- 817 core, at a depth of $63.0 \mathrm{~m}$, the content of $\mathrm{CaO}$ is $26.9 \%, \mathrm{MgO}-18.1 \%$, i.r. $-10.9 \%$.

In the stratotype area argillaceous, bioturbated dolostones occur only locally in the lower part of the Sauvere Beds. The Sauvere, Sõmera, Kogula, and Paadla localities (Suurlahe-738 core, depth 32.0-35.1 m; Kuressaare-804 core, depth $34.2-35.2 \mathrm{~m}$ ) exhibit the lower part of the beds with the same typical features. The rocks are wavy-bedded, with abundant unsorted shells of invertebrates and 
skeletal debris. The argillaceous complexes include frequent up to $1.5 \mathrm{~m}$ thick pure skeletal wackestone layers with Sauvere-type concentric burrows, and pyritized discontinuity surfaces. In the Sauvere-686 core (depth 1.5-6.9 m) the content of $\mathrm{CaO}$ is $28.67-46.3 \%, \mathrm{MgO}-2.47-19.28 \%$, i.r. $-4.18-8.0 \%$.

In the western part of the outcrop area (Atla-Riiumägi and Agama localities, Himmiste-982, depth 13.8-15.0 m, and Sõmera-I cores, depth 5.2-6.0 m; in Latvia: Kolka-54 core, depth 293.9-298.0 m) the limestones contain small stromatoporoid and coral bioherms, intercalating with skeletal grainstones and kerogenous limestones in the lower and middle parts of the beds (e.g. Himmiste- 880 core, depth 7.8-9.0 m). The chemical composition of the coral-limestones is variable: $\mathrm{CaO}$ $46.08-50.39 \%, \mathrm{MgO}-1.98-6.64 \%$, i.r. - 2.48-4.57\%.

Adjacent to the biohermal limestone area, the Lümanda quarry and Möldri core (depth 29.8-38.4 m) exhibit predominantly medium- to thick-bedded, wavy or horizontal fine-grained skeletal grainstones alternating with pelletal packstones and skeletal wackestones. The chemical composition of the skeletal, pelletal packstones in the Lümanda quarry is as follows: $\mathrm{CaO}-45.3-53.35 \%, \mathrm{MgO}-$ $1.03-7.82 \%$, i.r. $-1.36-6.23 \%$.

In the Ohesaare core the Sauvere Beds are represented by calcitic domerites, which upwards are replaced by argillaceous, dolomitic marls, nodular wackestones, and varigrained, skeletal packstones (Fig. 2; lithological column by R. Einasto in Märss 1986b, fig. 41).

The Himmiste Beds $\left(\mathrm{K}_{2} \mathrm{H}\right.$ in Fig. 2) form a small, $2-8 \mathrm{~m}$ thick cyclite in the middle of the Paadla Stage. The lower boundary of the Himmiste Beds is usually a distinct discontinuity surface overlain by skeletal limestones and underlain by lagoonal dolostones or domerites. The beds mainly contain Kaarma-type dolostones, dolomitic marls (domerites), and Eurypterus-dolostones alternating with fineto coarse-grained, skeletal grainstones and yielding stromatoporoids, ostracods, gastropods, and fish microremains.

Kaarma-type dolostones in eastern Saaremaa (Vätta-817 core, depth 51.3$54.0 \mathrm{~m}$; Kõiguste-833 core, depth 10.5-14.0 m) are conspicuous for the high content of insoluble residue (15.1-15.2\% in the Vätta-817 core, depth $53.1 \mathrm{~m}$, and Nässumaa-825 core, depth $51.0 \mathrm{~m}$ ). In middle Saaremaa, microlaminated argillaceous Eurypterus-dolostones or domerites contain often lingulid, eurypterid, and agnathan remains (Uduvere-968 core, depth 3.0-6.0 m; Kuressaare-804 core, depth 22.0-25.7 m; Suurlahe-738 core, depth 17.5-22.5 m). In the Nässumaa-825 and Kuressaare- 804 cores the lower part of the beds consists of domerites, the upper part of Kaarma-type dolostones. In the Suurlahe-738 core the Himmiste Beds are wholly represented by domerites yielding lingulids, eurypterids, and vertebrate microremains. Notable is the cross-bedded structure of the dolostones alternating with laminated Eurypterus-dolostone (e.g. in the Uduvere core, depth $3.8-5.0 \mathrm{~m}$ ). The cross-bedding is expressed by different size of skeletal debris indicative of different sedimentation conditions in the Uduvere-Kuressaare-Suurlahe area.

In the western part of the island, in the Himmiste- 880 core drilled on the brink of the quarry, argillaceous, calcitic dolostone of Kaarma type occurs in the 


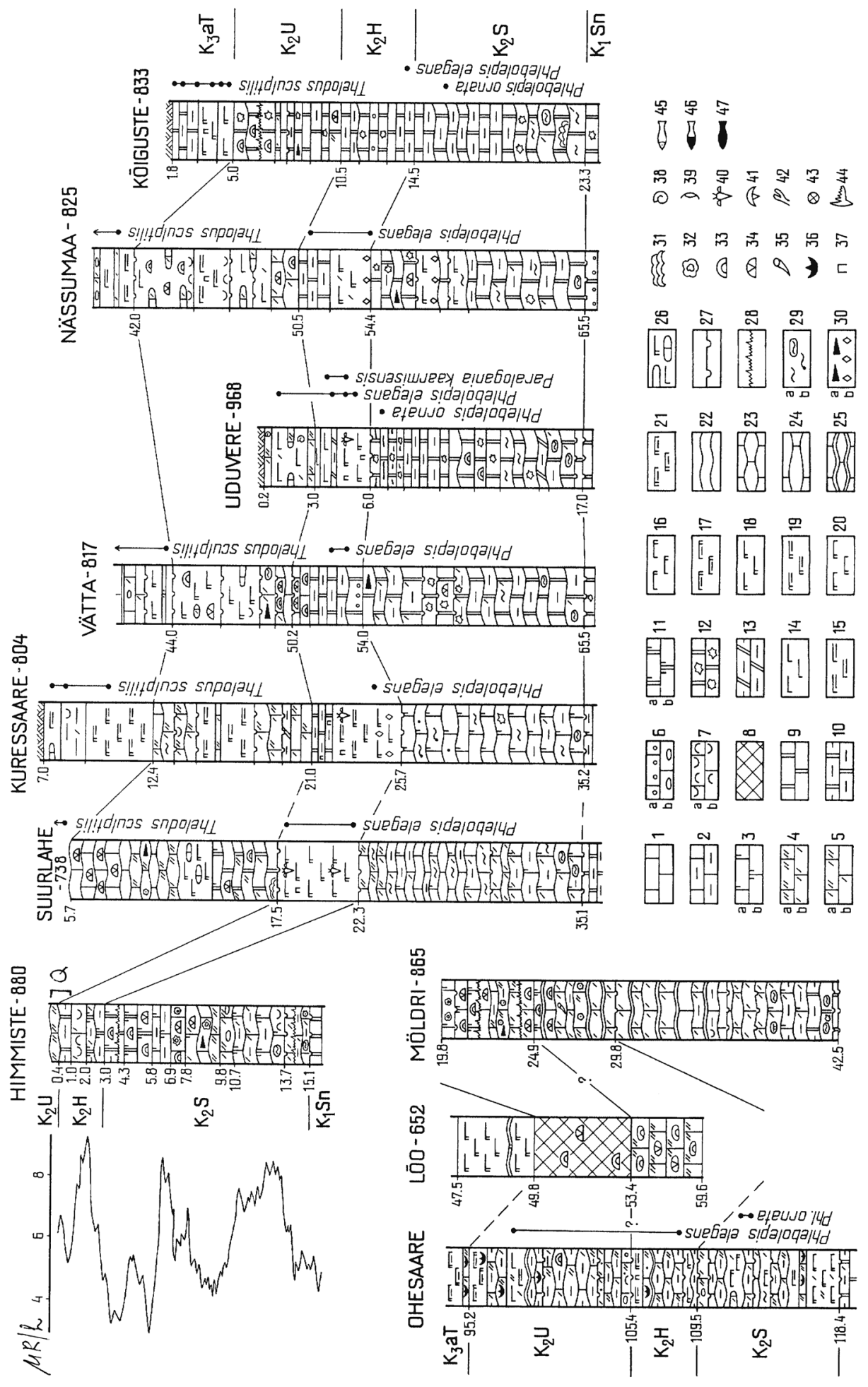


interval of $0.4-1.0 \mathrm{~m}$ (interval $0.4-3.0 \mathrm{~m}$ corresponds to the whole of the Himmiste Beds), which lower (depth 1.0-2.0 m) intercalates with coarse- and fine-grained, skeletal grainstone. In westernmost Saaremaa the lower part of the beds is built of algal and stromatopore-coral limestone (upper beds in the Lümanda quarry; Riksu-803 core, depth 23.3-25.7 m; Katri-990 core, depth 11.5-13.2 m; Roobimaa-881 core, depth 0.2-1.5 m), which higher in the section is replaced by greenish-grey, thick-bedded, argillaceous dolostones (Himmiste and Pilguse quarries). Southwards, the Lõo-652 core (depth 53.4-59.6 m) has yielded an over $6.2 \mathrm{~m}$ thick bioclastic stromatoporoid conglomerate with the coarsegrained, skeletal grainstone matrix. The Torgu Formation on the Sõrve Peninsula is represented by argillaceous nodular unsorted packstone (Ohesaare core, depth 105.4-109.5 m).

The Uduvere Beds $\left(\mathrm{K}_{2} \mathrm{U}\right.$ in Fig. 2$)$ have a variable thickness $(5-11 \mathrm{~m})$ and lithology. The lower boundary of the beds coincides with the boundary of the sedimentation cycle. The Uduvere Beds comprise argillaceous, nodular grainstones, rudstones, and packstones but also marlstone interbeds. The chemical composition of pure limestones in the Pähkla, Irase, and Uduvere quarries is similar and varies as follows: $\mathrm{CaO}-48.4-54.05 \%, \mathrm{MgO}-0.95-4.4 \%$, i.r. $-1.4-$ $4.24 \%$. East of Kuressaare the lower part of the beds consists of grey, varigrained, skeletal packstone, which is dolomitized in the Kõiguste-833 core (depth 7.4$10.5 \mathrm{~m}$ ). Higher parts of the sections have very variable lithology of light-grey or greenish-grey, calcareous domerites or marlstones (Nässumaa-825 core, depth 42.0-49.3 m; Uduvere-968 core, depth 0.2-2.4 m; Vätta-817 core, depth 44.0$48.4 \mathrm{~m}$ ), or kerogen-bearing dolostones (Kõiguste-833 core, depth 9.6-10.5 m). The domerites are porous to vuggy, argillaceous, with horizontal microlamination. Brachiopods, ostracods, gastropods, and stromatolites are common in the limestone

Fig. 2. Lithological logs and stratigraphy of the core sections of the Paadla Stage on Saaremaa Island. Top left in the figure: gamma-log of the Himmiste- 880 core, measured in micro-roentgen per hour. Legend (after Nestor 1990, p. 30): 1-3, limestones: 1, in general; 2, argillaceous; 3a, dolomitic; 3b, highly dolomitic; 4, skeletal grainstone: (a) coarse, (b) fine; 5a, unsorted skeletal packstone; $5 \mathrm{~b}$, fine-grained skeletal wackestone; $6 \mathrm{a}$, pelletal grainstone; $6 \mathrm{~b}$, conglomerate; $7 \mathrm{a}$, coquinoid rudstone; $7 \mathrm{~b}$, floatstone; 8 , boundstone (biohermal limestone); 9-13, dolostones: 9 , in general; 10, argillaceous; 11a, calcitic; 11b, highly calcitic; 12, vuggy (porous); 13, Eurypterus-dolostone; 14-17, marlstones: 14, calcareous; 15, argillaceous; 16, dolomitic; 17, dolomitic, argillaceous; 18-21, domerites: 18, calcareous; 19, argillaceous; 20, calcitic; 21, calcitic, argillaceous; 22, wavy bedding; 23, nodular limestone; 24, seminodular limestone; 25, nodular limestone with clayey intercalations; 26, limestone nodules in marlstones and domerites; 27, discontinuity surface; 28, stylolites; 29a, horizontal burrows and burrows in nodules (of Sauvere type); 29b, pyritized burrows; 30a, kerogen; 30b, breccia; 31, stromatolites; 32, oncolites; 33, stromatoporoids; 34, tabulate corals; 35, rugose corals; 36, brachiopods; 37, pyrite mottles; 38, gastropods; 39, ostracods; 40, eurypterids; 41, trilobites; 42, bryozoans; 43 , pelmatozoans; 44, conodonts; 45 , disarticulated agnathan remains; 46, articulated shields; 47, articulated squamations; Q, the beds corresponding to those in the Himmiste-Kuigu quarry. Stratigraphical indices: $\mathrm{K}_{1} \mathrm{Sn}$, Soeginina Beds of the Rootsiküla Stage; $\mathrm{K}_{2} \mathrm{~S}$, Sauvere Beds; $\mathrm{K}_{2} \mathrm{H}$, Himmiste Beds; $\mathrm{K}_{2} \mathrm{U}$, Uduvere Beds of the Paadla Stage; $\mathrm{K}_{3} \mathrm{aT}$, Tahula Beds of the Kuressaare Stage. The depth is in metres. 
bands (Kotlandi-866 core, depth 9.5-18.0 m). The lower part of the Uduvere Beds is slightly dolomitized in the Suurlahe-738 section (depth 13.5-17.0 m). In eastern Saaremaa, where the sections are often secondarily dolomitized, this interval is represented by vuggy kerogenous dolostones (Kõiguste-833 core, depth 8.8-10.5 m). West of Paadla and on the Sõrve Peninsula stromatopore-coral bioherms and pelletal packstones characterize the Uduvere Beds. For example, in the Sorve-514 core section (depth 144.6-146.8 m), the biohermal limestones appear only at the top of the Uduvere Beds. In the western part of the outcrop area, stromatoporoid and coral boundstones occur in the middle of the Uduvere Beds (Katri cliff, Kotlandi-866 core, depth 16.0-18.0 m; Kipi core, depth 0.6$4.4 \mathrm{~m}$; Möldri-865 core, depth 23.0-23.5 m; Kaugatuma core, depth 57.6$61.6 \mathrm{~m}$ ). Southwards, in the Lõo-652 core (depth 49.8-53.4 m) on the Sorrve Peninsula they are replaced by a very thick ( $3.6 \mathrm{~m}$ for the Uduvere Beds) stromatoporoid-conglomerate bank with frequent red baryte crystals in its whole vertical range (9.8 $\mathrm{m}$ for the Himmiste and Uduvere beds). Pelletal packstones have been described in the Ohesaare core, depth 102.0-105.4 m (Einasto in Märss 1986b, fig. 41). The contact of the Uduvere Beds with the overlying Tahula Beds of the Kuressaare Stage ( $\mathrm{K}_{3} \mathrm{aT}$ in Fig. 2) is lithologically indistinct. Argillaceous dolostones and domerites occur in both stratigraphical units, and thus the boundary is determined by vertebrates and conodonts.

\section{FISH BED IN THE HIMMISTE-KUIGU QUARRY}

\section{Quarry section}

The Himmiste-Kuigu quarry is situated on western Saaremaa. Today its area is about $50 \times 25 \mathrm{~m}$. In the section the upper part of the Himmiste and the basal part of the Uduvere beds crop out. The quarry is the type locality of the Himmiste Beds of the Paadla Stage and one of the boundary localities of the Himmiste and Uduvere beds. The section (Fig. 3a), described from top to base with thickness of beds shown, is as follows (Märss \& Einasto 1990, p. 169):

$0.2 \mathrm{~m}$ - Grey, argillaceous, wavy-bedded limestone with varigrained skeletal debris and some lenses of grainstone; a thin $(0.5 \mathrm{~cm})$ argillaceous intercalation occurs in the lower part.

$0.15 \mathrm{~m}$ - Buff-grey, skeletal packstone or grainstone with pellets, skeletal psammite, pebbles, and oncolites; a thin $(1 \mathrm{~cm})$ domerite intercalation is at the base and a sharp discontinuity surface at the top. This bed forms the transgressive basal part of a mesocyclite.

$0.4 \mathrm{~m}$ - Yellow-grey, microlaminated, argillaceous dolostone; the top is marked by a discontinuity surface constituting the boundary of the Himmiste and Uduvere beds.

$0.2+\mathrm{m}$ - Light-grey to greenish-grey, thick-bedded, microlaminated, argillaceous dolostone. 


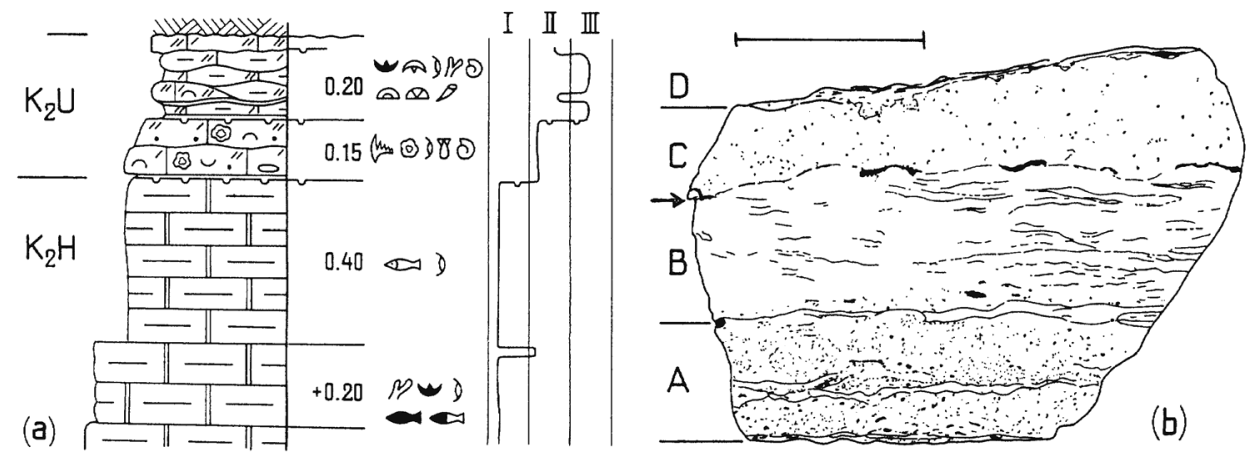

Fig. 3. (a) Lithological log of the Himmiste-Kuigu quarry section. I-III, facies belts (for legend see Fig. 2). (b) Cross-section of the fish bed, slab TUG 865-3A. The dolostone is represented by: A, dolopackstone layer; B, dolomudstone layer with P. elegans exoskeletons on the top; C, dolowackestone layer; D, (?)discontinuity surface (terminology after Viira \& Einasto 2003). The thickness of the beds is in centimetres.

There is no authentic publication saying exactly which beds thelodont and osteostracan specimens come from. The most logical conclusion is that they were collected from the bed just above the floor of the quarry.

\section{Microlithology of the fish bed}

The fish bed consisting of grey dolostone was studied microlithologically. For that purpose a corner of slab TUG 865-3A with the fish bed fully preserved in a thickness of $10.0 \mathrm{~cm}$ (maximum thickness of the fish bed is $14 \mathrm{~cm}$ in slab TUG 865-16) was cross-sectioned and polished. It was possible to distinguish four layers differing from each other in the content of clay, skeletal fragments, and bedding structures (Pl. I, fig. 1; Fig. 3b). We use the terminology of Viira \& Einasto (2003) for the dolostone structure varieties (i.e. dolowackestone, dolopackstone, and dolomudstone).

Layer $\mathrm{A}$ at the base is represented by $3.2 \mathrm{~cm}$ thick dolopackstone containing invertebrate shell fragments. Approximately in the middle of it there is a $0.2 \mathrm{~cm}$ thick wavy dolomudstone lamina. Layer B is $3.8-4.5 \mathrm{~cm}$ thick microlaminated dolomudstone. The basal $3-5 \mathrm{~mm}$ of it contain some skeletal debris which disappears higher in the layer. The upper $2 \mathrm{~cm}$, just below the fish skeletons, is bioturbated. P. elegans skeletons are lying at a low angle inside the fish bed. Layer $\mathrm{C}$ is $2.0-3.0 \mathrm{~cm}$ thick dolowackestone without any lamination, containing less skeletal debris than layer A. Layers A-C can be treated as sedimentation microcycles, and dolomudstone deposition occurred as one event of sedimentation. Layer $\mathrm{D}$ at the top of the fish bed is $0.1-0.3 \mathrm{~cm}$ thick brownish dolostone, which could be an impregnation zone of the discontinuity surface or just a weathered rock. 


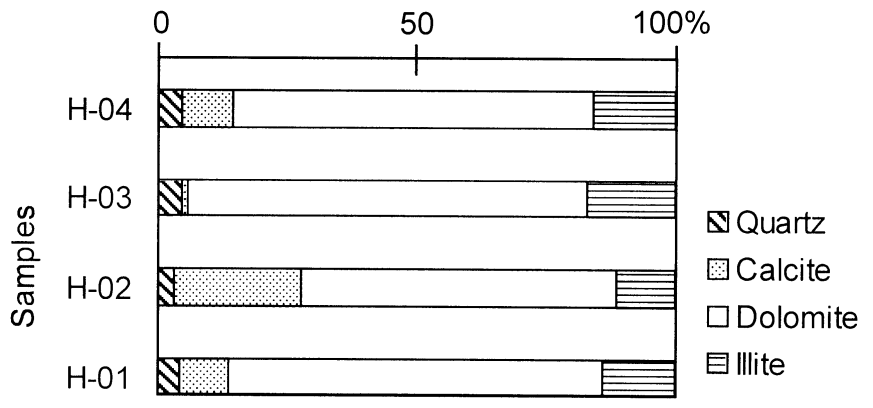

Fig. 4. Mineralogical composition of the fish bed. Samples H-01, H-03, and H-04 are from layer B (TUG 865-9B, TUG 865-25, and TUG 865-3A, respectively); sample H-02 is from layer C (TUG 865-1B).

In the mineral composition, dolomite (60-80\%) prevails in all samples (Fig. 4). Samples H-01 and H-04, taken from dolomudstone layer B (TUG 865-9B and TUB 865-3A, respectively), are similar in both lithology and mineralogy. Sample $\mathrm{H}-02$ from dolowackestone layer $\mathrm{C}$ has more calcite, and less dolomite, quartz, and illite than samples $\mathrm{H}-01$ and $\mathrm{H}-04$. Sample $\mathrm{H}-03$ differs from the three others in higher dolomite and illite contents, but a lower calcite content. Still, this sample is probably from layer B.

\section{The age of the fish bed}

The Himmiste Beds of the Paadla Stage correspond to the Phlebolepis elegans Biozone, which is preceded by P. ornata in the upper Sauvere Beds and succeeded by the Thelodus sculptilis Biozone higher in the Tahula Beds of the Kuressaare Stage (Fig. 2). The list of agnathans of the Himmiste Beds in the Himmiste-Kuigu quarry contains thelodonts Thelodus laevis (Pander), T. carinatus (Pander), Thelodus sp., Paralogania martinssoni (Gross), Phlebolepis elegans Pander, osteostracans Tremataspis mammillata Patten, Dartmuthia gemmifera Patten, Oeselaspis pustulata Patten, Procephalaspis oeselensis (Robertson), and anaspids Schidiosteus mustelensis Pander and Pharyngolepis? sp. A (Märss 1986b; Blom et al. 2002). In the Himmiste-982 core, drilled about $250 \mathrm{~m}$ to the southwest of the quarry, the interval $0.7-3.1 \mathrm{~m}$ contains the same taxa but in the interval of 1.7-1.9 m also Paralogania kaarmisensis Märss scales have been found. This species occurs also in the Uduvere-968 core (for other localities see

\section{Explanation of Plate I}

Fig. 1. Cross-section of the fish bed. Slab TUG 865-3A. Himmiste-Kuigu quarry, Saaremaa, Estonia; Himmiste Beds of the Paadla Stage, Ludlow, upper Silurian.

Fig. 2. Phlebolepis elegans Pander "shoal". Slab TUG 865-5B, Himmiste-Kuigu quarry, Saaremaa, Estonia; Himmiste Beds of the Paadla Stage, Ludlow, upper Silurian. Scale bar $=5.0 \mathrm{~cm}$. 
PLATE I

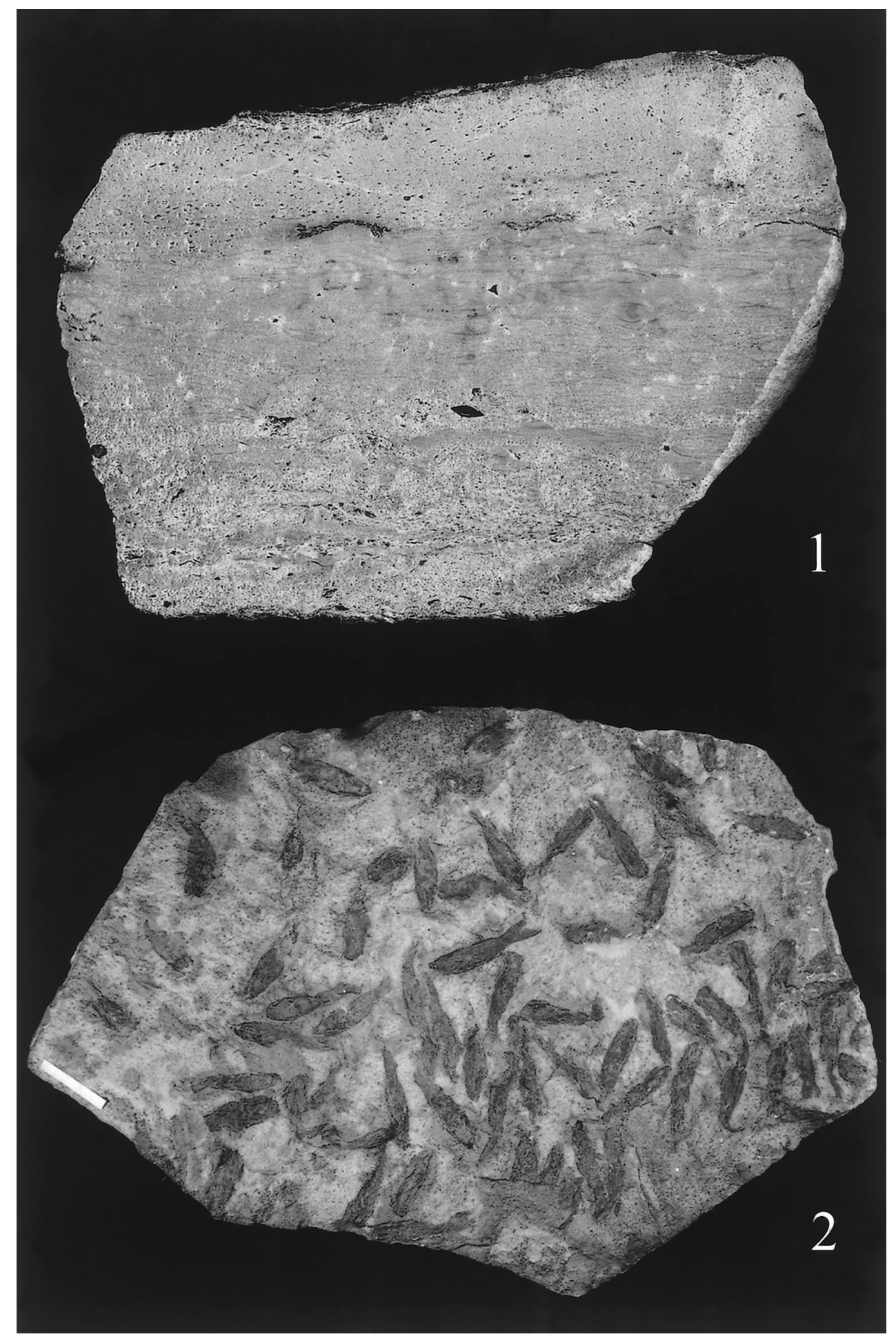



Märss 2003). It has a very short vertical range in the P. elegans Biozone. The scales of both P. elegans and Par. kaarmisensis have also been identified in the Late Bringewood (Gorstian) and Early Leintwardine (Ludfordian) of the Welsh Borderland, Britain (Märss \& Miller in press), allowing corresponding correlations.

\section{DESCRIPTION OF FOSSIL MATERIAL}

Phlebolepis elegans Pander was a small, up to $7 \mathrm{~cm}$ long, fusiform thelodont with the dorso-ventrally flattened anterior part of the head. The rest of the body was laterally compressed, with antero-laterally placed orbits, a nearly terminal mouth, paired lateral (pectoral), dorsal and anal fins, and a strong caudal fin (Ritchie 1968). The body of $P$. elegans was covered with scales of different size and specific sculpture, the trunk scales partly overlapping each other (see Märss 1986a).

In the material studied, only a few specimens have paired pectoral fins preserved, but the dorsal and anal fins are more often present. Quite a few specimens have a caudal fin (Pl. I, fig. 2). The caudal fin appeared to be much more complex than supposed or described earlier: it is just slightly asymmetrical and built of fine ray-like lobes (pseudo-rays) between two stronger ones like in Loganellia scotica (see Märss \& Ritchie 1998); the "rays" are covered with scales. For the first time distinct evidence of the pineal opening was obtained from the scale pattern on the head (new data on P. elegans will be published elsewhere).

Most of the well-preserved P. elegans specimens are of the same size. Exoskeletons lie generally laterally, less often on undifferentiated dorsal or ventral sides. The squamations are either compressed or depressed on the bedding plane; three-dimensional specimens are rare. Some depressed exoskeletons are in semicircular position. Many bodies have gone through plastic depression, with the thickened wall of the squamation, which is not broken on the sides, running along the margin of the body. The squamations are unevenly distributed on the slabs. They are most numerous, tightly packed, sometimes even partly covering each other, and best preserved in the middle of the $14 \mathrm{~cm}$ thick fish bed. The slabs with sloping dolomudstone surfaces (layer B) contains sparse fossils in the upper part but more in the lower part. The rock surrounding the specimens of the lower part is light grey and that of the upper part - light yellowish-grey (or olivegreen if the rock is wet).

As a rule, articulated skeletons or shields of other agnathans are not found on the same bedding plane with $P$. elegans. Our material contains only one specimen of Dartmuthia gemmifera and Tremataspis mammillata Patten from inside the fish bed, while disarticulated scales and small shield fragments of different agnathans occur throughout the dolostones of the quarry (Fig. 3a).

Six sets of larger slabs (part and counterpart, where available) were chosen for counting the specimens of P. elegans and establishing the orientation of their exoskeletons (Fig. 5a-f). The number of specimens in the sets varies from 64 to 114 . 
Slabs TUG 865-5A and 865-5B (Fig. 6a; Pl. I, fig. 2). The part and counterpart do not overlap exactly. The scales are cocoa-brown to reddish-brown and very well preserved. The specimens are tightly packed in a zone that stretches through the surface of the slabs; here some specimens partly cover each other. Altogether 102 specimens were counted from the part and counterpart, and the orientation of the longitudinal axes of their bodies was measured. One main direction of squamations is distinguished; four second-level peaks point to the opposite direction (Fig. 5a).

Slabs TUG 865-3A-D. There are four pieces of rock, one from the lower and three (one of them with a small additional piece) (Fig. 6b) from the upper part of the fish bed. The lower and upper parts do not overlap exactly. The scales are coffee-brown and relatively well preserved. Altogether 114 specimens were counted. One main peak was observed, with three to four second-level peaks on both sides (Fig. 5f).

Slab TUG 865-6 (Fig. 7a). The slab from the lower part of the fish bed is not well split into two. Rather well preserved specimens are exposed mostly on one margin of the slab, on the rest of the surface they are sparse and fragmentary or hidden in the rock. The rock is grey, the squamations are cocoa-brown. Altogether 75 specimens on the slab are orientated in three more pronounced directions (Fig. 5b).

Slabs TUG 865-14A-F (see Fig. $7 b$ for TUG 865-14A). A. Luha had six slabs numbered 14. We were not able to put all those pieces together because the original margins of some slabs were not preserved. The thickness of the upper

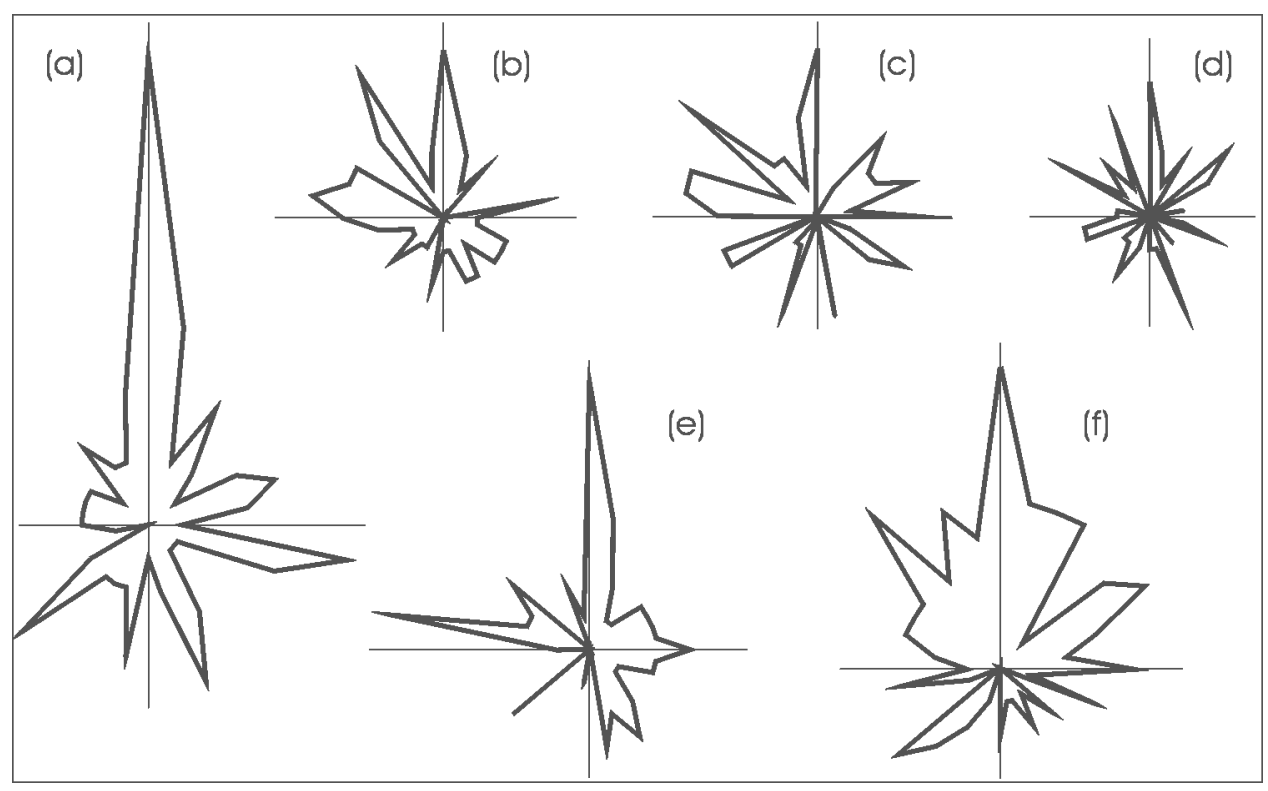

Fig. 5. Orientation of Phlebolepis elegans Pander exoskeletons on the slabs. (a) TUG 865-5, (b) TUG 865-6, (c) TUG 865-10, (d) TUG 865-9, (e) TUG 865-14A,F, and (f) TUG 865-3. The main direction is coincided with the top of the drawing. 


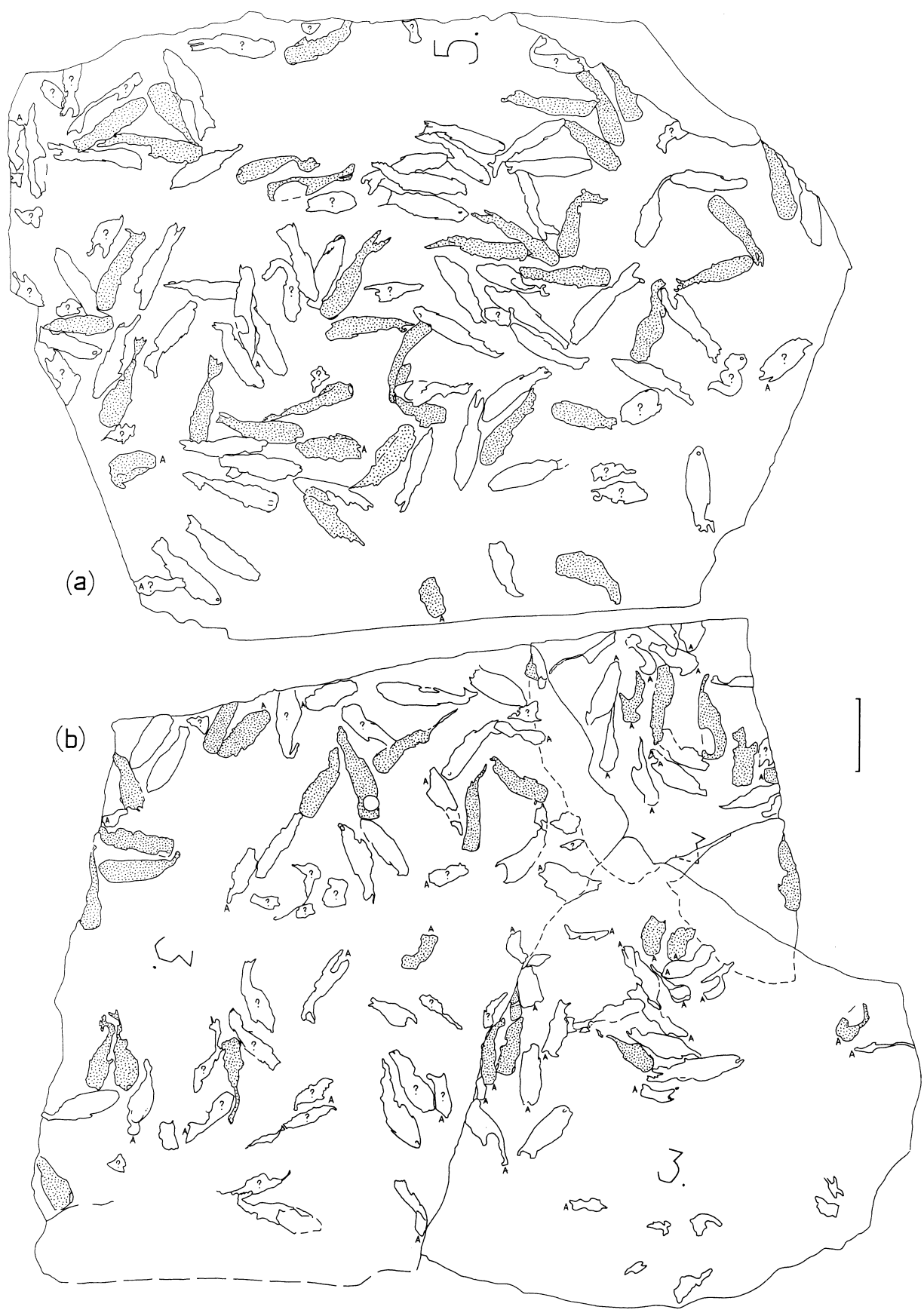

Fig. 6. Distribution of Phlebolepis elegans Pander squamations in the fish bed from the HimmisteKuigu quarry. (a) slab TUG 865-5A, (b) slab TUG 865-3B-D. Scale bar for both drawings $=5 \mathrm{~cm}$. The letter A points to the anterior in incomplete specimens; empty fish image marks the specimens lying laterally; spotted fish images show the bodies whose anterior part is lying either dorsally or ventrally; the question mark indicates that no side is distinguished. 


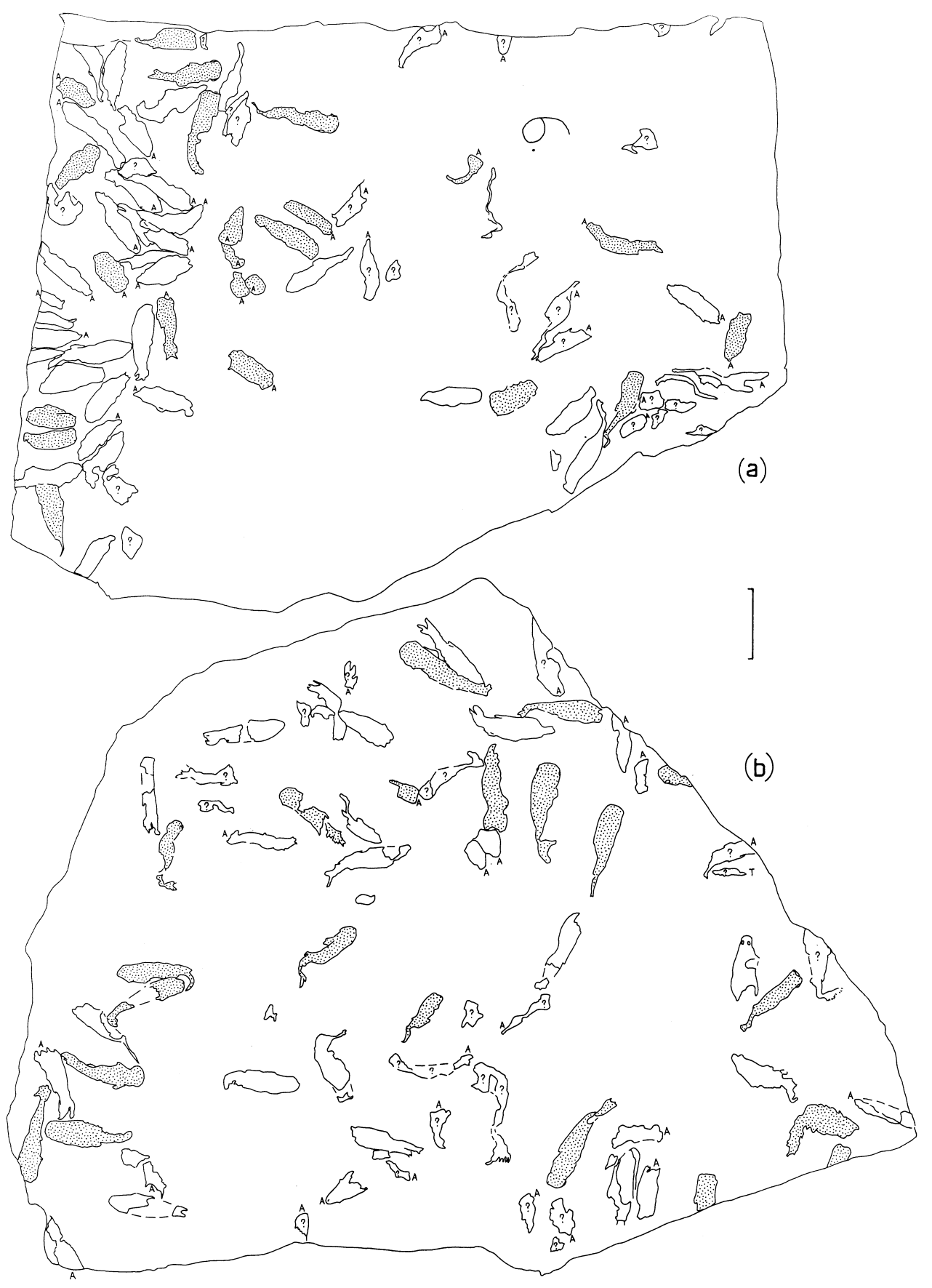

Fig. 7. Distribution of Phlebolepis elegans Pander squamations in the fish bed from the HimmisteKuigu quarry. (a) slab TUG 865-6, (b) slab TUG 865-14A. Scale bar for both drawings $=5 \mathrm{~cm}$. For the rest of the legend see Fig. 6. 
and lower parts of the fish bed varies drastically. For example, the thickness of $45 \mathrm{~cm}$ wide slab TUG 865-14E (the upper part of the bed) changes from 2 to $8 \mathrm{~cm}$. Slabs TUG 865-14A and TUG 865-14F, the part and counterpart, are of the same size and were used for the analysis. Coffee-brown scale covers, 69 in number, are not very well preserved. The squamations are oriented in one main direction, the difference from the second-level direction being about 80 degrees (Fig. 5e).

Slabs TUG 865-9. Both the lower and upper parts consist of smaller pieces partly glued together, the set of the lower parts being larger and having more exoskeletons preserved (Fig. 8a). The orientation of 47 squamations is rather uniform in all directions (Fig. 5d).

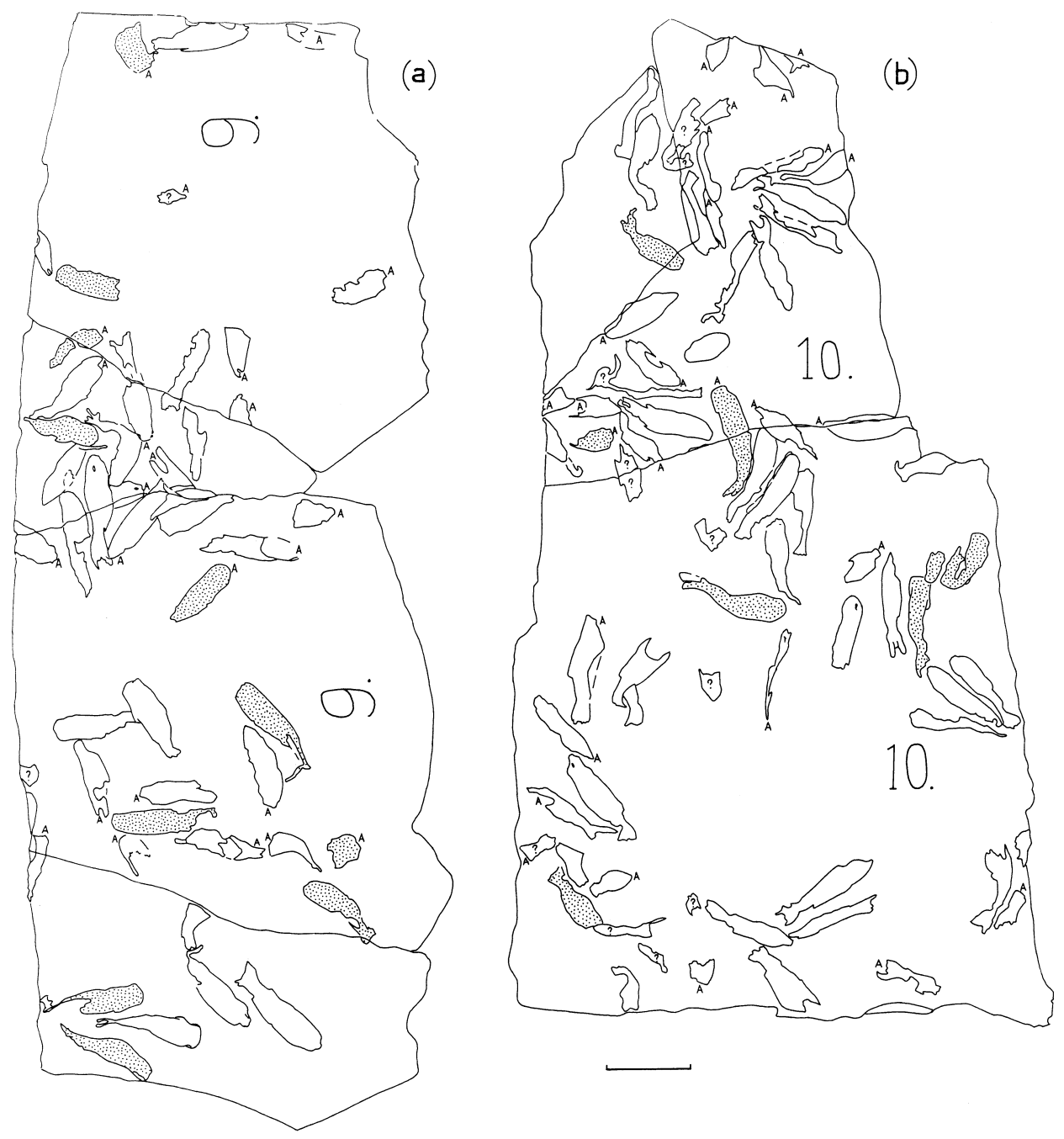

Fig. 8. Distribution of Phlebolepis elegans Pander squamations in the fish bed from the HimmisteKuigu quarry. (a) slab TUG 865-9A,B, (b) slab TUG 865-10A,B. Scale bar for both drawings = $5 \mathrm{~cm}$. For the rest of the legend see Fig. 6. 
Slabs TUG 865-10A,B (Fig. 8b). Three smaller plates fit together, forming a big slab of $64.0 \times 34.5 \mathrm{~cm}$. As the slab is too heavy to handle, it is kept in two parts. There is no arrow carved on the rock sides but considering the grey colour of the surface, the plate should be the lower part of the fish bed. The squamations have mainly preserved as moulds. If preserved, the scales are light-beige or even white. The orientation of 65 specimens is rather uniform, with three slightly prevailing directions (Fig. 5c).

Slabs TUG 865-19 (Fig. 9a), TUG 865-4 (Fig. 9b), TUG 865-20 (Fig. 9c), and TUG 865-21 (Fig. 9d) are rich in P. elegans exoskeletons but as the number of specimens is too small to give any valid result, their orientation was not measured. Many of these squamations are beautifully preserved for morphological studies.

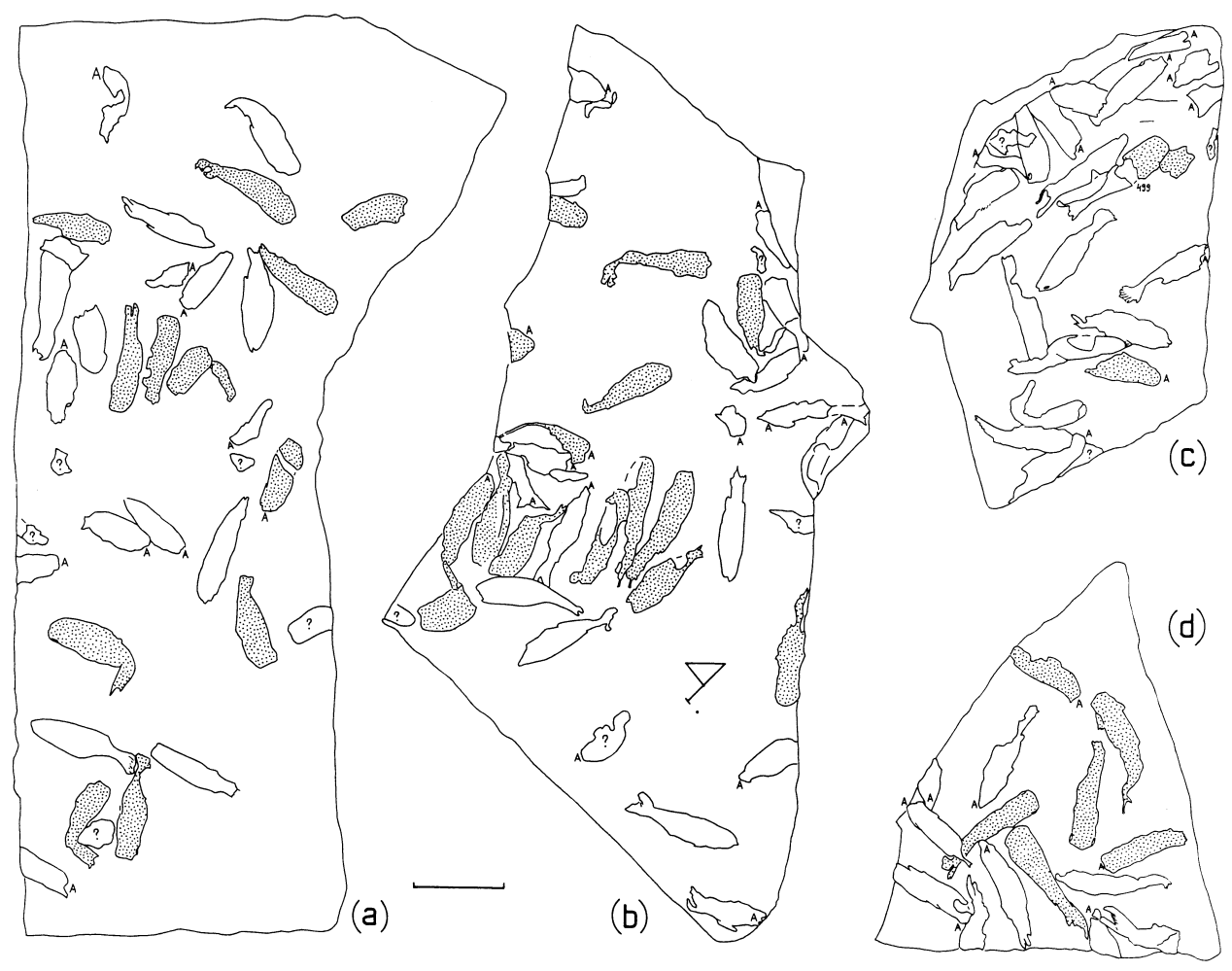

Fig. 9. Distribution of Phlebolepis elegans Pander squamations in the fish bed from the HimmisteKuigu quarry. (a) slab TUG 865-19, (b) slab TUG 865-4, (c) slab TUG 865-20, and (d) slab TUG $865-21$. Scale bar for all drawings $=5 \mathrm{~cm}$. For the rest of the legend see Fig. 6 . 


\section{FACIES DISTRIBUTION DURING PAADLA TIME}

In the Silurian the East Baltic was part of a shallow cratonic sea in the tropics, in which carbonate and fine clastic sediments accumulated and which was well connected with the oceanic basin in Central Europe (Kaljo \& Jürgenson 1977; Nestor \& Einasto 1977, 1997). The lagoonal and shoal facies extended over a very wide area of southwestern Estonia, covering the entire levelled shelf plateau during the late Wenlock and middle Ludlow (Nestor \& Einasto 1997, p. 202). The general distribution of facies belts in the Baltic Basin is provided by Nestor \& Einasto (1997, fig. 149). For the Saaremaa area, three facies belts are given for the mid-Paadla Age: lagoonal dolomitic mud, followed towards the open sea by pelletal-skeletal sand and silt, and bioclastic calcareous mud.

Our studies of lithology revealed much more complex sedimentation conditions and facies development for the area, with the reef belt playing an essential role. During the Wenlock and Ludlow extensive reef-building took place in the Palaeobaltic (Klaamann \& Einasto 1982). The reef belt separating a wide lagoonal area in the east from the open shelf in the west existed throughout the Paadla Age, changing its position in the course of the transgressive-regressive phases of the sea.

At the end of Sauvere time (Fig. 10a) a narrow NW-SE reef belt proceeded from Sõrve towards Elda (bioherms of the Agama and Atla-Riiumägi quarries). Winnowed skeletal-pelletal sandy sediments deposited eastwards of the reef belt, while the remainder of Saaremaa was covered with lagoonal muds. The western part of this lagoonal area was represented by the argillaceous calcareous muds (bioturbated packstones) of restricted shelf, which were eastwards replaced by sedimentary argillaceous dolomitic muds (dolostones of Kaarma type). Southwards the muds were kerogenous.

The second half of Himmiste time (Fig. 10b) showed a regressive trend in the development of the sea. The lagoonal area of dolomitic muds (dolostones of Kaarma type) widened noticeably westwards and nearly reached the previous reef belt area, which in turn was shifted towards the open sea. The lagoon was separated from the reef belt by only a narrow zone of bioclastic sediments with corals and stromatoporoids. Exceptional was the deposition of cross-bedded dolomitic skeletal sand in the middle of the lagoon, indicating different sedimentation conditions in that area. Eurypterids, lingulids, and agnathans were common in the lagoon with dolomitic mud sedimentation.

A transgression started at the beginning of Uduvere time. The reef belt shifted eastwards, permeating the Lõo area and the west coast of Saaremaa at Katri. The belt of bioclastic sediments widened considerably eastwards, up to the Vätta area. The area closer to the reef belt was rich in corals and stromatoporoids, farther, at Suurlahe - in stromatolites. The dolomitic muds (dolostones of Kaarma type) deposited east of Kaali, behind the area of kerogenous sedimentation with corals. In the Lõo area, the biohermal complex contains stromatopore conglomerate interbeds with reddish, up to $0.5 \mathrm{~cm}$ fragments of baryte $\left(\mathrm{BaSO}_{4}\right)$. Baryte was possibly formed in the environment with alternating marine and terrestrial 


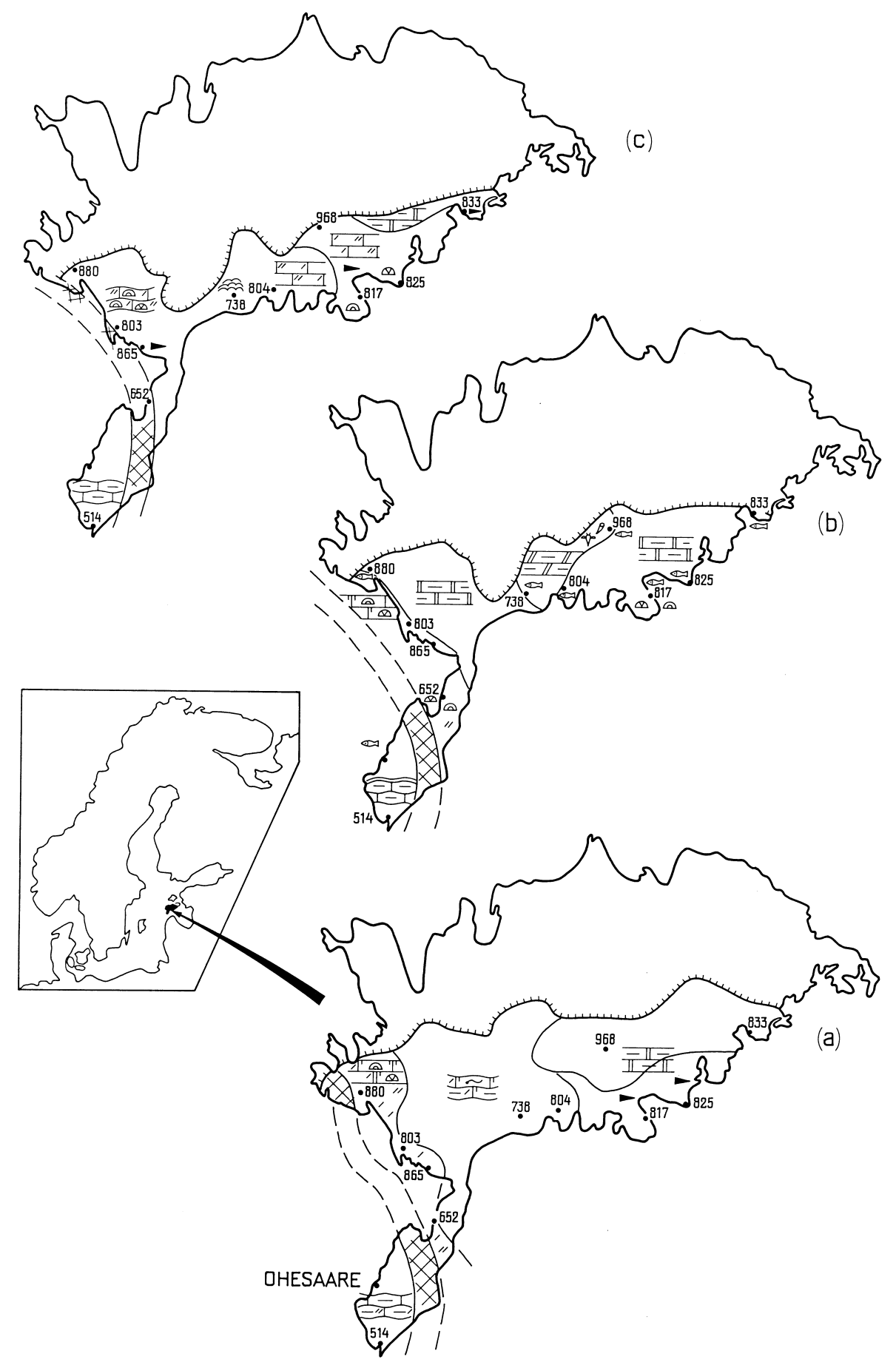

Fig. 10. Geological development of the area: (a) late Sauvere, (b) late Himmiste, and (c) early Uduvere time. For legend see Fig. 2. 
conditions and probable occurrence of sedimentation gaps (A. Kleesment, pers comm. 2003).

During these three stages of the development of the sea, the open shelf belt occurred west of the reef belt. In that belt calcareous sediments (argillaceous nodular limestones of the Torgu Formation) deposited.

\section{BURIAL CONDITIONS OF THE PHLEBOLEPIS ELEGANS PANDER SHOAL}

Fish exoskeletons can preserve intact only in specific conditions depending on the anatomy of fishes, hydrochemical, hydrodynamical, and geological situation. Studies on modern fishes in the North Sea revealed different preservation of their bodies in the same environmental conditions (temperature, salinity, water agitation) (Schäfer 1962). In that work (pp.67-68) two main groups are distinguished: (1) Fish whose bodies remained on the sea floor during the whole decay and therefore preserved well. Their abdominal cavities were very small and therefore the production of gases was too low to raise the body to the water surface. (2) Fish which after death sank to the bottom. Their abdominal cavities filled with gases during decay and they rose up to the water surface. When the stomach-walls and skin broke and the abdominal cavities were emptied of the gases, the bodies sank again, at the same time drifting away with the waves or currents from the place where they lived and died. Whether the body rose up or not depended also on whether the stomach and intestine were infilled or empty because fermentation of food remains produced gases (ibid., p. 70). Such bodies never remained intact. Higher temperature caused quicker formation of gases and also decay; higher salinity slowed down the process due to slower bacterial treatment. The final treatment of bodies was done by the scavengers. The sooner the bodies were covered by the sediment, the better the skeletons were preserved (Schäfer 1962).

During the Silurian the Palaeobaltic basin was situated in tropical latitudes. Phlebolepis elegans Pander lived in shoals and inhabited widely the open waters of the shelf and deeper parts of the seas (Märss 1986b). Both the macro- and microlithological data confirm that the lagoon with calcareous mud deposition, connected with the open sea over the reef belt, prevailed in the Himmiste-Kuigu area during late Himmiste time. Already Aaloe (1963) suggested that a wide shallow area or island lay west or southwest of Saaremaa, separating the lagoon from the open sea. Dolomudstone layer B (Fig. 3b) hints at very quiet waters (see also Märss \& Einasto 1978): it does not contain organic matter and is very weakly microlaminated, but bioturbated by Phlebolepis around the skeletons. Dolopackstones below (layer A) and dolowackestones (layer C) above the dolomudstone layer contain detritus of echinoderms, brachiopods, and ostracods, showing a more agitated zone. The beds are secondarily dolomitized. 
The burial of Phlebolepis at Himmiste-Kuigu has not been studied in detail, but two different opinions prevail about the deposition of another group of agnathans - osteostracans - at the same site. Mostly only their head shields have been found; only one osteostracan has the head shield and squamation intact. Robertson (1938), explaining the accumulation of that material, accepted its transportation down the stream or the rolling and sorting action of currents. According to Bölau (in Aaloe 1963, p. 89), the osteostracans were buried where the animals lived, because their shields did not bear any sign of transportation. Two osteostracan shields in our collection come from dolowackestone layer $\mathrm{C}$, formed in more agitated water conditions, while P. elegans was found on dolomudstone layer B.

In the tropical climate, where Himmiste-Kuigu was situated during the Silurian, the decay process was obviously shorter than shown by Schäfer (1962) for modern fishes in the North Sea. The squamations of P. elegans are differently preserved, but mainly intact; nearly all specimens have lost their most delicate lateral fins and bear no sign of transportation. These agnathans lived widely in the sea, but their intact exoskeletons were buried where they died. Their burial site might have been the gently sloping bottom of the Himmiste lagoon with shallow depressions which existed landward behind the reef belt. The Phlebolepis elegans Pander shoal was caught in such a depression (the irregular oval quarry at the site of the exhausted fish lens measures about $20 \times 50 \mathrm{~m}$ ), which during the following low tide acted as a trap where the fish shoal died in a few days due to oxygen deficiency and lack of food. The bodies did not rise to the surface and drift aside, either because their abdominal cavities were too small or stomachs (if Phlebolepis had such) were empty, producing not enough gases, or the depression was too shallow to allow any shifting. After death, the bodies were immediately covered by the soft homogeneous light-grey carbonate mud of the same sedimentation microcycle, and later on with the mud with disperse invertebrate and vertebrate skeletal debris of the next sedimentation microcycle. The sorting by waves or currents was not strong as it would have broken the weakly integrated squamations. There was perhaps very weak water undulation or wind influence, because the bodies show one main direction of orientation on most of the slabs. The skeletons were well preserved because calcareous mud (dolomudstone layer B) prevented them from disintegration. The calcareous mud around the bodies somewhat compacted before the next sediment layer (dolowackestone layer $\mathrm{C}$ ) was brought into the depression. Therefore the mudstone layer with thelodonts was not damaged, except that the squamations were compressed by the weight of sediments deposited on them. It seems that this shallow depression with fishes did not dry up, because mud cracks or evidences of hardground have not been discovered between layers $\mathrm{B}$ and $\mathrm{C}$.

Different interpretations of the salinity in the Himmiste lagoon are available. Robertson (1938, p. 186) concluded that the deposition took place in normalmarine waters. According to Denison (1956) and Hoppe (1931), there were shallow nearshore brackish waters where the agnathans lived. Aaloe (1963) was of the opinion that from time to time the water in the basin was of abnormal salinity due 
to (1) a wide shallow area or island between the lagoon and the open sea, and (2) a river or temporary streams (flows) that brought fresh water into the lagoon. It is obvious that the above-described reef belt, which was influenced by ebbs and tides, played an important role in the water exchange and living conditions in the lagoon. Significant characteristics of the Himmiste lagoon were the area of the alternation of cross-bedded skeletal sand and Eurypterus-mud in middle Saaremaa, and a high content of insoluble residue in the eastern area. These may point to an underwater area influenced by a stream as suggested by Aaloe (1963).

\section{SUMMARY}

- The sedimentation conditions during the Paadla Age and formation of the Himmiste-Kuigu fish bed have been discussed using new lithological evidences from several drill cores.

- During late Himmiste time, the lagoon in the Himmiste-Kuigu area was connected with the open sea over the reef belt in the west.

- P. elegans inhabited waters on both sides of the reef belt. A shallow depression in the lagoon acted as a trap during low tide unfavourable for fishes.

- Individual specimens of P. elegans Pander are of the same size and thus of the same age. They formed a shoal which perished completely during a single event of grey carbonate mud deposition.

- The type of sediments, distribution of bodies and their preservation indicate quiet-water conditions in a shallow lagoonal facies belt poor in skeletons of other organisms.

- The P. elegans shoal has preserved in a lens-like fish bed with rare ostracods and a few osteostracans (Tremataspis and Dartmuthia) occurring on the same bedding plane, while most of osteostracan and anaspid exoskeletons were buried under more agitated water conditions.

- The Phlebolepis exoskeletons preserved lie mainly on the lateral side, more rarely on the ventral (or dorsal?) side; a few specimens are whirled semicircularly.

- Due to a weak water undulation or wind activity the specimens are oriented in one main direction.

- The exoskeletons were quickly buried in the sediment, which prevented their disintegration.

\section{ACKNOWLEDGEMENTS}

Our appreciation is extended to all who made this study possible. The photos were made by G. Baranov; K. Ronk drew the final versions of the drawings; A. Kleesment, Institute of Geology at Tallinn Technical University (TTU), assisted with orientation diagrams and interpretation of minerals; L. Ainsaar and K. Kirsi- 
mäe, Institute of Geology, University of Tartu, and R. Einasto and H. Nestor, Institute of Geology at TTU, provided help in microlithological interpretations; K. Kirsimäe also completed XRD analyses of the mineralogical composition of the fish bed; S. Peetermann improved our English; T. Nuuma, Tartu, was a patient and helpful fellow member of the expedition to Saaremaa in 2002. Our thanks go to both referees, Drs. H. Nestor (Tallinn) and E. Lukševičs (Riga). The study was financed by the Estonian Science Foundation (grant No. 4160).

\section{REFERENCES}

Aaloe, A. 1963. On the stratigraphic position and conditions of sedimentation containing Tremataspis mammillata. ENSV TA Geol. Inst. Uurimused, XIII, 83-90 (in Russian).

Aaloe, A., Kaljo, D., Klaamann, E., Nestor, H. \& Einasto, R. 1976. Stratigraphical classification of the Estonian Silurian. ENSV TA Toim. Keemia Geol., 25, 38-45 (in Russian).

Blom, H., Märss, T. \& Miller, G. C. 2002 (for 2001). Silurian and earliest Devonian Birkeniid anaspids from the Northern Hemisphere. Trans. Roy. Soc. Edinburgh Earth Sci., 92, 263 323.

Denison, R. H. 1956. A review of the habitat of the earliest vertebrates. Fieldiana: Geology, 11, $359-457$.

Einasto, R. 1990. Kaarma quarry. In Field Meeting, Estonia 1990. An Excursion Guidebook (Kaljo, D. \& Nestor, H., eds.), p. 173. Tallinn.

Hoppe, K.-H. 1931. Die Coelolepiden und Acanthodier des Obersilurs der Insel Ösel. Ihre Paläobiologie und Paläontologie. Palaeontographica, 76, 35-94.

Hoppe, K.-H. 1934. Phlebolepis elegans Pander aus dem Obersilur der Insel Ösel. Zentralblatt Mineralogie Geologie Paläontologie, 1933 (Abt. B, 2), 124-130.

Kaljo, D. \& Jürgenson, E. 1977. Sedimentary facies of the East Baltic Silurian. In Facies and Fauna of the Baltic Silurian (Kaljo, D., ed.), pp. 122-148. Valgus, Tallinn (in Russian).

Kiaer, J. (ed. by Heintz, A.). 1932. New coelolepids from the upper Silurian of Oesel (Esthonia). Publ. Geol. Inst. Tartu University, 27, 1-8.

Klaamann, E. \& Einasto, R. 1982. Coral reefs of Baltic Silurian (structure, facies relations). In Ecostratigraphy of the East Baltic Silurian (Kaljo, D. \& Klaamann, E., eds.), pp. 35-41. Valgus, Tallinn.

Luha, A. 1940. Uusi ostrakoderme Saaremaa Eurypterus-lademest. Eesti Loodus, 1, 17-24.

Märss, T. 1979. Lateral line sensory system of the Ludlovian thelodont Phlebolepis elegans Pander. ENSV TA Toim. Geol., 28, 108-111 (in Russian).

Märss, T. 1986a. Squamation of the thelodont agnathan Phlebolepis. J. Vertebrate Paleontol., 6, $1-11$.

Märss, T. 1986b. Silurian vertebrates of Estonia and West Latvia. Fossilia Baltica, 1. Valgus, Tallinn (in Russian with extended English summary).

Märss, T. 2003. Paralogania from the Rootsiküla (Wenlock) and Paadla (Ludlow) stages of Estonia. Proc. Estonian Acad. Sci.. Geol., 52, 98-112.

Märss, T. \& Einasto, R. 1978. Distribution of vertebrates in deposits of various facies in the North Baltic Silurian. ENSV TA Toim. Keemia Geol., 27, 16-22 (in Russian).

Märss, T. \& Einasto, R. 1990. Himmiste quarry. In Field Meeting, Estonia 1990. An Excursion Guidebook (Kaljo, D. \& Nestor, H., eds.), pp. 169-170. Tallinn.

Märss, T. \& Miller, C. G. Thelodonts and distribution of associated conodonts from the Llandoverylowermost Lochkovian of the Welsh Borderland. Palaeontology (in press).

Märss, T. \& Ritchie, A. 1998. Articulated thelodonts (Agnatha) of Scotland. Trans. Roy. Soc. Edinburgh Earth Sci., 88, 143-195. 
Nestor, H. 1990. Some aspects of lithology of the Ordovician and Silurian rocks. In Field Meeting, Estonia 1990. An Excursion Guidebook (Kaljo, D. \& Nestor, H., eds.), pp. 27-32. Tallinn.

Nestor, H. 1997. Silurian. In Geology and Mineral Resources of Estonia (Raukas, A. \& Teedumäe, A., eds.), pp. 89-106. Estonian Academy Publishers, Tallinn.

Nestor, H. \& Einasto, R. 1977. Facies-sedimentary model of the Silurian Paleobaltic pericontinental basin. In Facies and Fauna of the Baltic Silurian (Kaljo, D., ed.), pp. 89-121. Valgus, Tallinn (in Russian).

Nestor, H. \& Einasto, R. 1997. Ordovician and Silurian carbonate sedimentation basin. In Geology and Mineral Resources of Estonia (Raukas, A. \& Teedumäe, A., eds.), pp. 192-204. Estonian Academy Publishers, Tallinn.

Pander, C. H. 1856. Monographie der fossilen Fische der silurischen Systems der RussischBaltischen Gouvernements. Obersilurische Fische. Kaiserlichen Akademie des Wissenschaften, 37-91.

Patten, W. 1931. New ostracoderms from Oesel. Science, 73, 671-673.

Ritchie, A. 1968. Phlebolepis elegans, an Upper Silurian thelodont from Oesel, with remarks on the morphology of thelodonts. In Current Problems of Lower Vertebrate Phylogeny. 4th Nobel Symposium (Oervig, T., ed.), pp. 81-88. Stockholm.

Ritchie, A. 1980. The Late Silurian anaspid genus Rhyncholepis from Oesel, Estonia, and Ringerike, Norway. American Museum Novitates, 2699, 1-18.

Robertson, G. M. 1938. The Tremataspididae. Amer. J. Sci., 35, 172-206.

Schäfer, W. 1962. Aktuo-Paläontologie nach Studien in der Nordsee. Verlag Waldemar Kramer, Frankfurt am Main.

Viira, V. \& Einasto, R. 2003. Wenlock-Ludlow boundary beds and conodonts of Saaremaa Island, Estonia. Proc. Estonian Acad. Sci. Geol., 2003, 52, 213-238.

\title{
Himmiste-Kuigu kalakihi sedimentoloogia Eesti Ludlow's ja Phlebolepis elegans Pander (Thelodonti) parve tafonoomia
}

\author{
Tiiu Märss, Helle Perens ja Tiiu Klaos
}

Telodondi Phlebolepis elegans Pander soomuskatetega setted moodustusid Hilis-Siluri Paadla eal troopilises vööndis Paleobalti meres rifivööndi taga eksisteerinud laguunis. Suurem osa välisskelette lamab küljel, vähem soomuskatteid on säilinud dorso-ventraalselt lamendunult, kusjuures nende keha tagumine osa on vajunud küljele; vähesed sabad on pöördunud poolkaarjalt tagasi pea poole. Põhiosa soomuskatetest on jäänud ilma küljeuimedeta ja tihti ka sabauimeta. Põhinedes nii makro- kui ka mikrolitoloogilistele kivimi tunnustele ja faatsieste levikule Himmiste ajal, arvame, et telodondiparv jäi mõõna tõttu mõnesse madalasse lohku laguuni põhjal, mis toimis lõksuna. Ebasobivad tingimused, põhiliselt hapniku vähesus soojas ja madalas vees ning toidu puudus põhjustasid kalaparve hukkumise; õrn vee liikuvus ei hajutanud soomuseid. Soomuskatete kiire konserveerumine mudas vältis nende edasise lagunemise. 